\title{
Sistem Pendukung Keputusan Menentukan Pemutusan Hubungan Kerja Karyawan CV. Biring Ndu Cahaya Panglong Dengan Metode AHP
}

\author{
Eko Lianto Damanik ${ }^{1 *}$, R. Mahdalena Simanjorang ${ }^{2}$ \\ ${ }^{1,2}$ STMIK Pelita Nusantara \\ Jl. Iskandar Muda No. 1 Medan 20154 Indonesia \\ Corresponding author‘s e-mail: damaniklianto@gmail.com
}

\begin{abstract}
Abstrak - Saat ini CV. Biring Ndu Cahaya Panglong tidak memiliki sistem informasi yang mampu membantu dalam mengelola data karyawan. Data karyawan tersebut meliputi semua data yang berhubungan dengan aktivitas pengendalian karyawan. Metode AHP merupakan salah satu metode dalam sistem pendukung keputusan yang memiliki keunikan dibandingkan dengan yang lainnya. Ada 10 nama alternatif dan 5 kriteria dalam penentuan PHK yaitu Lalai Dalam bekerja (C1), Mangkir (C2), Pencurian Barang (C3), Tidak Rapih (C4), Menyebar Aib Perusahaan (C5). Hasil yang diperoleh dari penelitian ini dengan nilai tertinggi adalah Arya Sinaga dengan nilai 0,272 yang menandakan bahwa alternatif dengan ranking tertinggi akan diberhentikan dalam bekerja.
\end{abstract}

Kata kunci: SPK, Metode AHP, Penentuan PHK, Ranking

Abstract - CV Biring Ndu Cahaya Panglong is a company that sells various types of building materials and equipment, located in Tanah Merah village, Dusun II Pendukuan, Galang District. Currently CV. Biring Ndu Cahaya Panglong does not have an information system that is able to assist in managing employee data. The employee data includes all data related to employee control activities. The AHP method is one of the methods in decision support systems that is unique compared to the others. There are 10 alternative names and 5 criteria in determining layoffs, namely negligence in work (C1), absenteeism (C2), theft of goods (C3), not neat (C4), spreading company disgrace (C5). The results obtained from this study with the highest score is Arya Sinaga with a value of 0.272 which indicates that the alternative with the highest ranking will be dismissed from work. Keywords: SPK, AHP Method, Determination of Layoffs, Ranking

\section{Pendahuluan}

Setiap inovasi diciptakan untuk memberikan manfaat positif bagi ke-hidupan manusia, memberikan banyak kemudahan, serta sebagai cara baru dalam melakukan aktifitas manusia. Tidak bisa dipungkiri bahwa perkembangan tersbut berdampak pada beberapa aspek, salah satunya adalah dibidang pekerjaan seperti Pemutusan Hubungan Kerja (PHK). Pemutusan Hubungan Kerja (PHK) adalah momok yang sangat menakutkan bagi karyawan. Secara status, seseorang yang di PHK tidak lagi menyandang predikat karyawan di tempatnya bekerja semula. Kalau tidak segera dapat kerja baru, ancaman pengangguran ada di depan mata. Secara ekonomi, mereka yang di PHK bisa kehilangan sumber pencahariannya. Dalam hukum perburuhan di Indonesia UU No. 13 Tahun 2003 tentang Ketenaga kerjaan (UU Ketenaga kerjaan) mendefinisikan PHK sebagai pengakhiran hubungan kerja karena suatu hal tertentu yang mengakibatkan berakhirnya hak dan kewajiban antara pekerja dan pengusaha. Secara normatif, ada dua jenis PHK, yaitu PHK secara sukarela dan PHK dengan tidak sukarela. Ada beberapa alasan penyebab putusnya hubungan kerja yang terdapat dalam UU. Ketenagakerjaan. PHK sukarela misalnya, yang diartikan sebagai pengunduran diri buruh tanpa paksaan dan tekanan. Begitu pula karena habisnya masa kontrak, tidak lulus masa percobaan (probation), memasuki usia pensiun dan buruh meninggal dunia. PHK tidak sukarela dapat terjadi antara lain karena buruh melakukan kesalahan berat seperti mencuri atau menggelapkan uang milik perusahaan atau melakukan perbuatan asusila atau perjudian dilingkungan pekerjaan. CV. Biring Ndu Cahaya Panglong merupakan perusahaan yang menjual berbagai jenis material dan peralatan bangunan yang berlokasi di desa Tanah merah Dusun II Pendukuan Kecamatan Galang, yang berdiri sejak 30 Januari 2017.

Penelitian perubahan status karyawan kontrak menjadi karyawan tetap umumnya dilaksanakan perusahaan berdasarkan beberapa penilaian, namun sering merugikan para karyawan karena dianggap kurang adil. Perlu suatu metode seleksi yang transparan dan objektif. Sistem Pengambil Keputusan (SPK) dapat membantu memutuskan pengangkatan karyawan tetap dengan menggunakan metode Analitycal Hierarchy Process (AHP) [1]. Perhitungan AHP berdasarkan kriteria dan sub kriteria. Kriteria penilaian karyawan tetap berdasarkan kinerja, masa kerja, absensi, dan loyalitas[2]. Semakin besar nilai akhir yang diperoleh pada perhitungan AHP, peluang menjadi karyawan tetap semakin besar. Total perhitungan AHP diperoleh dari penjumlahan nilai dari setiap baris (Kinerja, Masa Kerja, Absensi, Loyalitas). Sebagai dasar untuk merangking penentuan pengangkatan karyawan kontrak menjadi karyawan tetap [3]. Semakin besar nilainya, pegawai tersebut akan 
semakin baik untuk menjadi karyawan tetap. Hasil perhitungan AHP dalam memutuskan menjadi pegawai tetap di PT. Timbang Deli yaitu Suwandi Daulay dengan nilai Kinerja $=0.558$, Masa Kerja $=0.263$, Absensi= 0.122 , Loyalitas $=0.023$, Total Nilai $=0.928$ [4].

Penelitian Penerapan Metode Analytical Hierarchy Process Dalam Sistem pendukung Keputusan Penentuan Mahasiswa Berprestasi, Setiap mahasiswa memiliki hak yang sama untuk mengikuti program pemilihan mahasiswa berprestasi. Oleh karena itu, sebaiknya pemilihan mahasiswa berprestasi dilakukan secara terbuka dan transparan pada tingkat perguruan tinggi. Namun pelaksanaan ini dapat menimbulkan banyaknya pendaftar yang dapat menyebabkan sulitnya mengelola data dan nilai dalam menentukan mahasiswa berprestasi [5]. Konsep sistem pendukung keputusan dapat diterapkan sebagai alat bantu dalam menentukan mahasiswa berprestasi. Salah satu metode yang relevan serta memiliki penghitungan nilai konsistensi dalam menentukan tingkat prioritas kriteria adalah metode AHP. Output dari penelitian ini merupakan sistem yang dapat memberikan rekomendasi alternatif penerima mahasiswa berprestasi dengan nilai indeks konsisten sebesar 0,06, sehingga hierarki yang dibentuk dapat diterima [6].

Penelitian Penerapan Analytical Hierarchy Process (AHP) pada Proses Pemilihan Supplier di Perusahaan Garment. Pembelian bahan baku sangat berpengaruh untuk kualitas produk yang dihasilkan sehingga bagaimana memilih supplier dari alternatif yang tersedia merupakan tahapan penting dalam proses pengadaan bahan baku terutama untuk perusahaan dengan banyak variasi produk dan berhubungan dengan banyak supplier seperti yang dihadapi oleh perusahaan garment. Pendekatan Analytical Hierarchy Process (AHP) merupakan pendekatan yang bi-asa digunakan sebagai alat untuk pengambilan keputusan dengan banyak alternatif pilihan [7].

\section{Tinjauan Pustaka}

\subsection{Sistem Pendukung Keputusan (SPK)}

Sistem pendukung keputusan merupakan sebuah sistem yang mampu memberikan kemampuan baik kemampuan pemecahan masalah maupun kemapuan pengkomunikasian untuk masalah semiterstruktur.sistem pendukung keputusan merupakan sistem yang membantu dalam mengambil keputusan secara cepat dan akurat pada sebuah masalah dengan memasukkan kriteria dan data-data yang relevan sehingga sistem ini dapat dijadikan sistem pengalihan pengambilan kepu-tusan. Sistem Pendukung Keputusan merupakan bagian dari pengembangan Sistem inforrmasi berbasis web yang menghasilkan beberapa alternatif keputusan guna membantu manajemen organisasi atau perusahaan dalam menangani berbagai permasalahan yang terstruktur maupun yang tidak terstruktur dengan menggunakan data dan model perancangan sistem [8] [9].

\subsection{Analytical Hierarchy Process (AHP)}

Metode AHP merupakan suatu model pendukung keputusan yang dikembangkan oleh Thomas L. Saaty. Model pendukung keputusan ini akan menguraikan masalah multi faktor atau multi kriteria yang kompleks menjadi suatu hirarki [10]. Menurut Saaty, hirarki didefinisikan sebagai suatu representasi dari sebuah permasalahan yang kompleks dalam suatu struktur multi level dimana level pertama adalah tujuan, yang diikuti level faktor, kriteria, sub kriteria, dan seterusnya ke bawah hingga level terakhir dari alternatif [11]. Dengan hirarki, suatu masalah yang kompleks dapat diuraikan ke dalam kelompok-kelompoknya yang kemudian diatur menjadi suatu bentuk hirarki sehingga permasalahan akan tampak lebih terstruktur dan sistematis [12].

Langkah-langkah metode AHP [13]:

1. Mendefinisikan masalah dan menentukan solusi yang diinginkan.

2. Membuat struktur hierarki yang diawali dengan tujuan utama.

3. Membuat matrik perbandingan berpasangan yang menggambarkan kontribusi relatif atau pengaruh setiap elemen terhadap tujuan atau kriteria yang setingkat di atasnya.

4. Melakukan Mendefinisikan perbandingan berpasangan sehingga diperoleh jumlah penilaian seluruhnya sebanyak $\mathrm{n} x[(\mathrm{n}-1) / 2]$ buah, dengan $\mathrm{n}$ adalah banyaknya elemen yang dibandingkan.

5. Menghitung nilai eigen dan menguji konsistensinya.

6. Mengulangi langkah 3, 4, dan 5 untuk seluruh tingkat hirarki.

7. Menghitung vektor eigen dari setiap matriks perbandingan berpasangan.

8. Memeriksa konsistensi hirarki.

AHP digunakan sebagai metode pemecahan masalah dibanding dengan metode yang lain karena alasanalasan :

1. Struktur yang berhirarki, sebagai konsekuesi dari kriteria yang dipilih, sampai pada subkriteria yang paling dalam. 
2. Memperhitungkan validitas sampai dengan batas toleransi inkonsistensi berbagai kriteria dan alternatif yang dipilih oleh pengambil keputusan..

3. Memperhitungkan daya tahan output analisis sensitivitas pengambilan keputusan.

\section{Metode Penelitian}

Tahapan dalam desain penelitian :

1. Tahap Identifikasi Masalah

Pada tahap ini merupakan pembahasan tentang masalah Pemutusan Hubungan Kerja Karyawan CV. Biring Ndu Cahaya Panglong. Tentunya harus dipahami dulu hal-hal apa saja atau permasalah-permasalahan apa saja yang muncul sebelum dilakukan pemecahannya.

2. Tahap Pengumpulan Data

Teknik Kepustakaan. Dilakukan dengan cara membaca dan mempelajari buku-buku yang terkait dengan judul penelitian dan literatur-literatur lainnya yang menunjang pelaksanaan penelitian. Pengamatan Langsung. Pengamatan langsung dilakukan dengan cara sosialisasi untuk mengetahui sejauh mana jangkauan promosi berpengaruh terhadap calon mahasiswa. Observasi. Teknik observasi yang dilakukan penelitian ini melalui observasi terbuka (overt observation). Dalam situasi ini peneliti teridentifikasi secara jelas dan selama observasi subjek sadar bahwa mereka sedang diobservasi. Teknik ini dilakukan untuk mengamati kondisi fisik dan peristiwa yang objektif terkait dengan Pemutusan Hubungan Kerja.

3. Tahap Analisis Data

Pada proses analisis data, peneliti menerapkan Metode AHP sebagai metode untuk men-golah data penelitian yang didapatkan pada teknik pengumpulan data. Terlebih dahulu peneliti melakukan proses persiapan pengolahan data dengan menganalisis susunan kriteria ke dalam struktur hirarki sesuai skala prioritasnya masing-masing lalu ditransformasikan ke arah solusi ideal positif dan terjauh dari solusi ideal negatif dari alternatif.

4. Tahap Proses Metode AHP

Pada tahap ini merupakan suatu proses dimana Pemutusan Hubungan Kerja karyawan diolah dengan menggunakan algoritma AHP. Dimana AHP merupakan metode untuk memecahkan suatu situasi yang komplek tidak terstruktur kedalam beberaa komponen dalam susunan ynag hirarki, dengan memberi nilai subjektif tentang pentingnya setiap variable secara relative, dan menetapkan variable mana yang memiliki prioritas paling tinggi guna mempengaruhi hasil pada situasi tersebut.

5. Tahap Perancangan Sistem

Bagian ini tentang bagaimana merancang sebuah sistem dengan menerapkan UML (Unified Modelling Language) dalam menggambarkan, mendesain, perangkat lunak yang akan dibangun.

6. Tahap Implementasi Sistem

Pada tahap implementasi sistem dilakukan proses yang bertujuan untuk menganalisa apakah fungsi sistem berjalan dengan baik dan mencari serta memperbaiki kemungkinan terjadi kesalahan pada sistem.

\section{Hasil dan Pembahasan}

Ada 5 (lima) kriteria yang digunakan yaitu Lalai dalam bekerja, mangkir, Pencurian barang, Tidak Rapih, Menyebarkan aib Peusahaan. Identifikasi kriteria dapat diinisialkan menjadi C (Kriteria).

Tabel 1. Kriteria Pemutusan Hubungan Kerja Karyawan

\begin{tabular}{|c|c|l|l|}
\hline No & $\begin{array}{c}\text { Kode } \\
\text { Kriteria }\end{array}$ & \multicolumn{1}{|c|}{ Nama Kriteria } & \multicolumn{1}{c|}{ Keterangan } \\
\hline 1 & C1 & Lalai Dalam bekerja & Tidak tepat aktu dalam penyelesaian pekerjaan \\
\hline 2 & C2 & Mangkir & Tingkat kehadiran dalam bekerja \\
\hline 3 & C3 & Pencurian Barang & Mengambil barang/Aset perusahaan \\
\hline 4 & C4 & Tidak Rapih & Penampilan karyawa tidak menarik \\
\hline 5 & C5 & $\begin{array}{l}\text { Menyebar Aib } \\
\text { Perusahaan }\end{array}$ & Tidak bisa menyimpan rahasia perusahaan \\
\hline
\end{tabular}

Setelah diketahui kriteria dan alternatif apa saja yang akan digunakan dalam menentukan pemutusan hubungan kerja karyawan, maka dibuat susunan hirarki permasalahan untuk menggambarkan cara mencari solusi penentuan pemutusan hubungan kerja karyawan seperti ditunjukkan pada Gambar 1 berikut ini: 


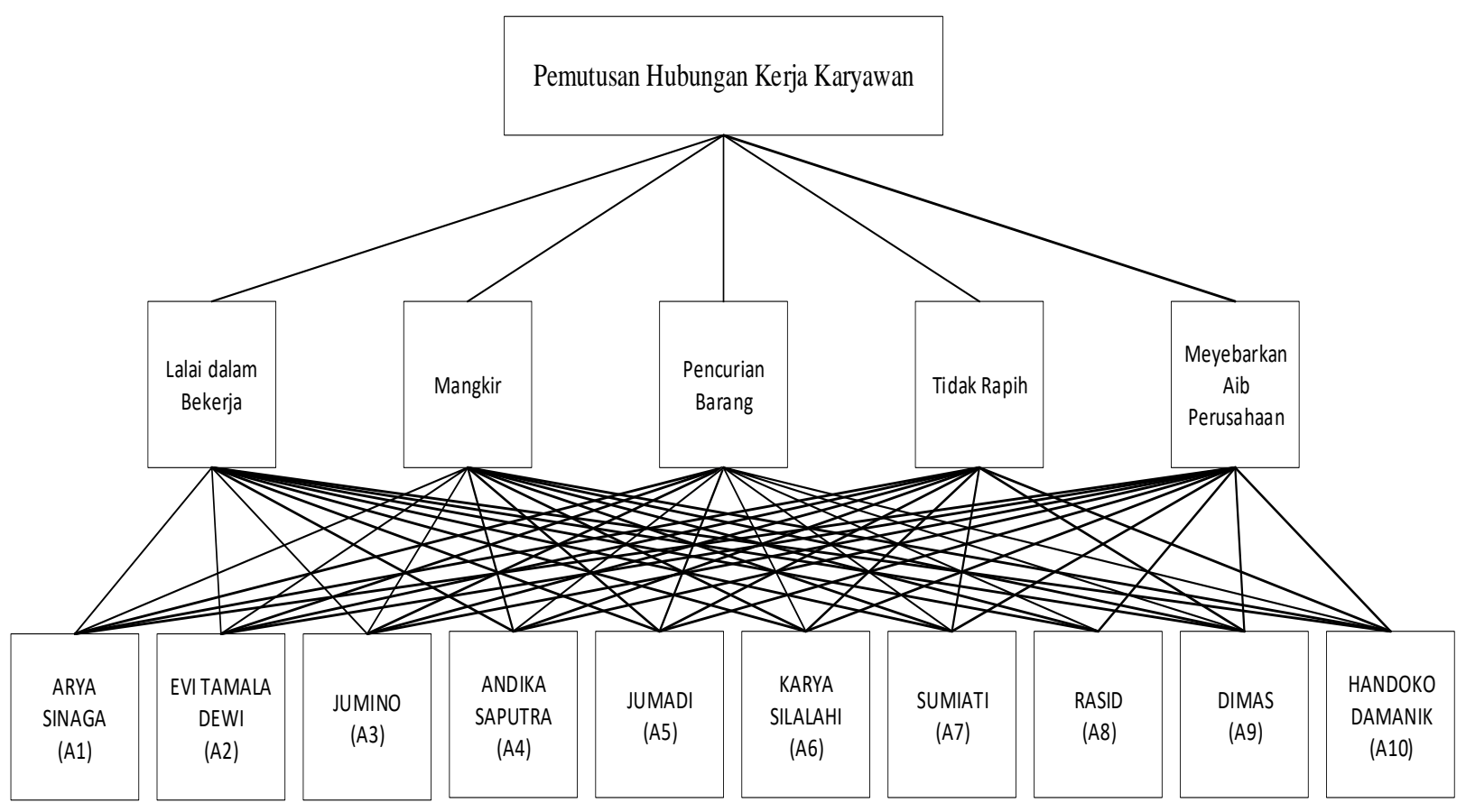

Gambar 1. Model Hirarki AHP

Ada 10 nama alternatif pada penelitian yaitu Arya Sinaga (A1), Evi Tamala Dei (A2), Jumino (A3), Andika Saputra (A4) Jumadi (A5), Karya Silalahi (A6), Sumiati (A7), Rasid (A8), Dimas (A9), Handoko Damanik (A10).

Tabel 2. Nilai Kriteria

\begin{tabular}{|l|c|l|}
\hline \multicolumn{1}{|c|}{ Kriteria } & \multicolumn{1}{|c|}{$\begin{array}{c}\text { Intensitas } \\
\text { Kepentingan }\end{array}$} & \multicolumn{1}{|c|}{ Keterangan } \\
\hline Lalai Dalam bekerja & 1 & Kedua elemen sangat penting \\
\hline Mangkir & 2 & $\begin{array}{l}\text { Nilai-Nilai antara dua nilai pertimabangan yang } \\
\text { berdekatan }\end{array}$ \\
\hline Pencurian Barang & 3 & $\begin{array}{l}\text { Elemen yang satu sedikit lebih penting, daripada elemen } \\
\text { lainnya. }\end{array}$ \\
\hline Tidak Rapih & 4 & $\begin{array}{l}\text { Nilai-Nilai antara dua nilai pertimbangan yang } \\
\text { berdekatan }\end{array}$ \\
\hline $\begin{array}{l}\text { Menyebar Aib } \\
\text { Perusahaan }\end{array}$ & & Kedua elemen lebih pentingdaripada elemen lainnya \\
\hline
\end{tabular}

Setelah diperoleh nilai bobot tingkat kepentingan masing-masing kriteria, maka tahap selanjutnya dilakukan pembuatan dan perhitungan matriks perbandingan berpasangan. Baris jumlah diperoleh dari hasil penjumlahan setiap kolomnya, dengan perhitungan seperti berikut ini: Kolom K1 = $1+0,5+0,33333+0,25+0,2=2.28333$. Kolom $\mathrm{K} 2=2+1+0,66667+0,5+0,4=4.56667$ Perhitungan selanjutnya dilakukan sampai kolom ke 5. Tahap selanjutnya adalah mekakukan pembagian nilai angka dengan jumlah setiap kolomnya.

Tabel 3. Hasil Matriks Perbandingan

\begin{tabular}{|c|c|c|c|c|c|}
\hline $\begin{array}{c}\text { Kriter } \\
\text { ia }\end{array}$ & $\mathrm{C} 1$ & $\mathrm{C} 2$ & $\mathrm{C} 3$ & $\begin{array}{r}\mathrm{C} \\
4\end{array}$ & $\mathrm{C} 5$ \\
\hline $\mathrm{C} 1$ & 1 & 2 & 3 & 4 & 5 \\
\hline $\mathrm{C} 2$ & 0,5 & 1 & 1,5 & 2 & 2,5 \\
\hline
\end{tabular}

Tabel 4. Normalisasi Matriks

\begin{tabular}{|c|c|c|c|c|c|}
\hline $\begin{array}{c}\text { Kriter } \\
\text { ia }\end{array}$ & C1 & C2 & C3 & C4 & C5 \\
\hline $\mathrm{C} 1$ & $\begin{array}{c}0.437 \\
96\end{array}$ & $\begin{array}{c}0.437 \\
96\end{array}$ & $\begin{array}{c}0.435 \\
15\end{array}$ & $\begin{array}{c}0.439 \\
56\end{array}$ & $\begin{array}{c}0.440 \\
53\end{array}$ \\
\hline
\end{tabular}




\begin{tabular}{|c|c|c|c|c|c|}
\hline $\mathrm{C} 3$ & $\begin{array}{c}0,333 \\
33\end{array}$ & $\begin{array}{c}0.666 \\
67\end{array}$ & 1 & $\begin{array}{c}1, \\
3\end{array}$ & 1,6 \\
\hline $\mathrm{C} 4$ & 0,25 & 0,5 & $\begin{array}{c}0.769 \\
23\end{array}$ & 1 & 1,25 \\
\hline $\mathrm{C} 5$ & 0,2 & 0,4 & 0.625 & $\begin{array}{c}0, \\
8\end{array}$ & 1 \\
\hline $\begin{array}{c}\text { Jumla } \\
\mathrm{h}\end{array}$ & $\begin{array}{c}2.283 \\
33\end{array}$ & $\begin{array}{c}4.566 \\
67\end{array}$ & $\begin{array}{c}6.894 \\
23\end{array}$ & $\begin{array}{c}9, \\
1\end{array}$ & $\begin{array}{c}11,3 \\
5\end{array}$ \\
\hline
\end{tabular}

\begin{tabular}{|c|c|c|c|c|c|}
\hline \multirow{2}{*}{$\mathrm{C} 2$} & 0.218 & 0.218 & 0.217 & 0.219 & 0.220 \\
& 98 & 98 & 57 & 78 & 26 \\
\hline \multirow{2}{*}{$\mathrm{C} 3$} & 0.145 & 0.145 & 0.145 & 0.142 & 0.140 \\
& 99 & 99 & 05 & 86 & 97 \\
\hline \multirow{2}{*}{$\mathrm{C} 4$} & 0.109 & 0.109 & 0.111 & 0.109 & 0.110 \\
& 49 & 49 & 58 & 89 & 13 \\
\hline \multirow{2}{*}{$\mathrm{C} 5$} & 0.087 & 0.087 & 0.090 & 0.087 & 0.088 \\
& 59 & 59 & 66 & 91 & 11 \\
\hline
\end{tabular}

Berdasarkan data matriks Normalisasi dapat dicari skala bobot prioritas setiap Kriteria dengan cara menghitung rata-rata baris; Rata-rata baris $\mathrm{K} 1=(0,43796+0,43796+0,43515+0,43956+0.44053)=2,19116 / 5=0,438232$ lakuakan perhitungan seterusnya hingga baris K5. Dari hasil perbandingan kriteria dan perbandingan alternatif diperoleh hasil perhitungan, Tabel 5.

Tabel 5. Hasil Perhitungan AHP

\begin{tabular}{|c|c|c|c|c|c|c|}
\hline $\begin{array}{c}\text { Overall } \\
\text { Composite } \\
\text { Height }\end{array}$ & $\begin{array}{c}\text { Priority } \\
\text { Vector (rata- } \\
\text { rata) }\end{array}$ & Arya Sinaga & $\begin{array}{c}\text { Evy Tamala } \\
\text { Dei }\end{array}$ & Jumino & $\begin{array}{l}\text { Andika } \\
\text { Saputra }\end{array}$ & Jumadi \\
\hline $\begin{array}{l}\text { Lalai dalam } \\
\text { bekerja }\end{array}$ & 0.43823 & 0.3438 & 0.18476 & 0.20476 & 0.14925 & 0.11744 \\
\hline Mangkir & 0.21912 & 0.2617 & 0.25806 & 0.17903 & 0.18512 & 0.1161 \\
\hline $\begin{array}{l}\text { Pencurian } \\
\text { Barang }\end{array}$ & 0.14417 & 0.22911 & 0.23621 & 0.20253 & 0.1687 & 0.16345 \\
\hline Tidak Rapih & 0.11012 & 0.09739 & 0.18976 & 0.17442 & 0.34885 & 0.18958 \\
\hline $\begin{array}{l}\text { Penyebar aib } \\
\text { perusahaan }\end{array}$ & 0.08837 & 0.23397 & 0.21006 & 0.14718 & 0.27497 & 0.13383 \\
\hline \multicolumn{2}{|c|}{ Total } & 0.27243 & 0.21102 & 0.19037 & 0.193 & 0.13317 \\
\hline
\end{tabular}

Tampilan hasil rancangan, Halaman Utama, Halaman utaman adalah halaman awal/tampilan awal yang kita lihat saat berhasil login. Dalam halaman ini ditemukan beberapa menu, yaitu home, kriteria, karyawan, perbandingan kriteria, perbandingan karyawan, hasil dan log out, tampilan halaman utama, Gambar 2.

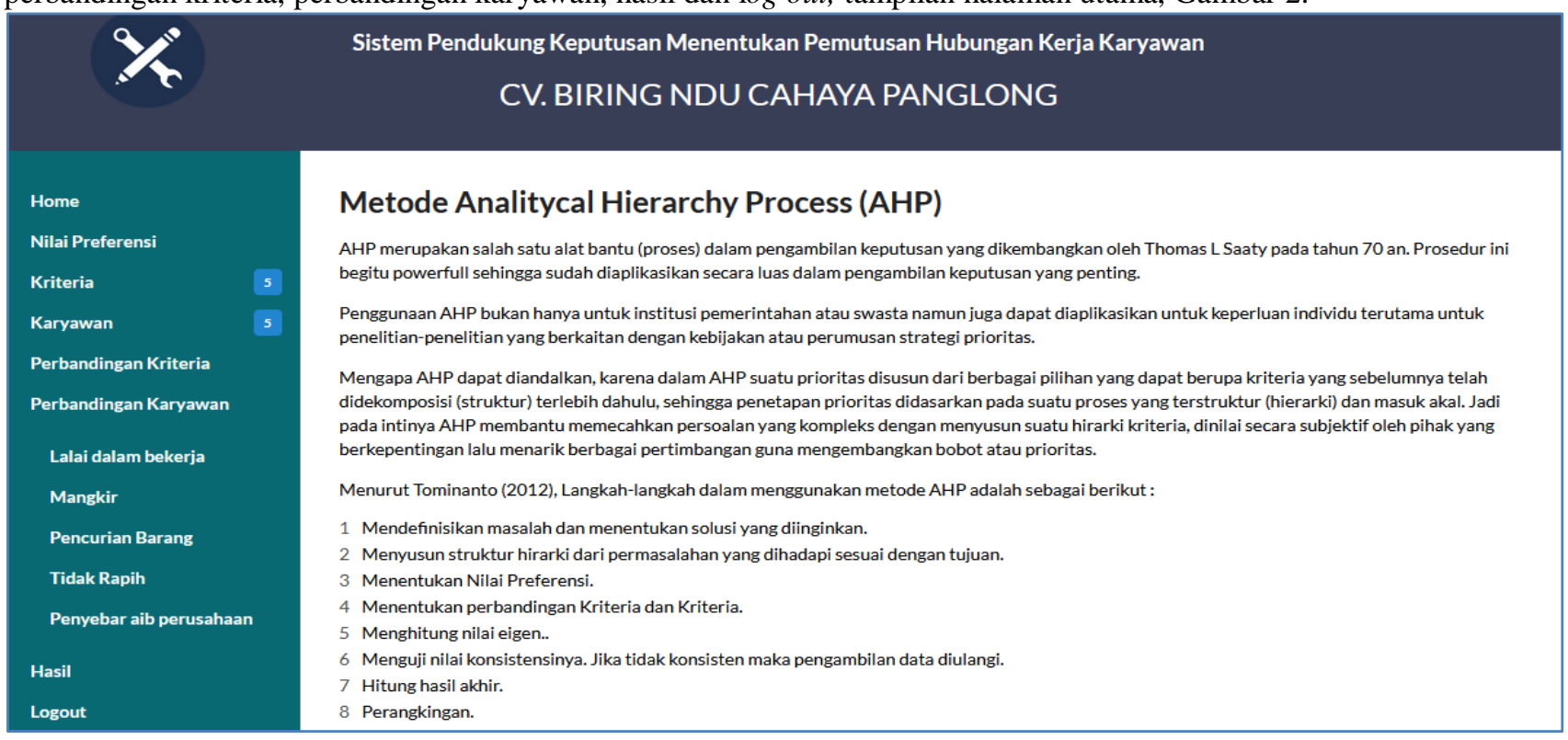

Gambar 2. Halaman Utama

Pada menu Nilai Preferensi ini akan didapatkan 9 angka yang sering di gunakan dalam Metode AHP mulai dari angka 1 sampai 9 yang menjadi hasil perbandingan dari nasing-masing elemen dimana skala perbandingan 
dan makna yang menjadi nilai insetitas kepentingan, Gambar 3.

\begin{tabular}{|c|c|c|}
\hline Home & \multicolumn{2}{|c|}{ Nilai Preferensi } \\
\hline Nilai Preferensi & \multirow{2}{*}{\multicolumn{2}{|c|}{$\begin{array}{l}\text { Hasil perbandingan dari masing-masing elemen akan berupa angka dari } 1 \text { sampai } 9 \text { yang menunjukkan perbandingan tingkat kepentingan suatu elemen. } \\
\text { Apabila suatu elemen dalam matriks dibandingkan dengan dirinya sendiri maka hasil perbandingan diberi nilai 1. Skala } 9 \text { telah terbukti dapat diterima } \\
\text { dan bisa membedakan intensitas antar elemen. }\end{array}$}} \\
\hline Kriteria & & \\
\hline $\begin{array}{ll}\text { Karyawan } & 5 \\
\text { Perbandingan Kriteria } & \end{array}$ & \multicolumn{2}{|c|}{$\begin{array}{l}\text { Hasil perbandingan tersebut diisikan pada sel yang bersesuaian dengan elemen yang dibandingkan. Skala perbandingan perbandingan berpasangan dan } \\
\text { maknanya yang diperkenalkan oleh Saaty bisa dilihat di bawah. Intensitas Kepentingan }\end{array}$} \\
\hline Perbandingan Karyawan & 1 & Sama Penting Dengan \\
\hline Lalai dalam bekerja & 2 & Mendekati Lebih Penting Dari \\
\hline Pencurian Barang & 3 & Sedikit Lebih Penting Dari \\
\hline Tidak Rapih & 4 & Mendekati Lebih Penting Dari \\
\hline Penyebar aib perusahaan & 5 & Lebih Penting Dari \\
\hline Hasil & 6 & Mendekati Sangat Penting Dari \\
\hline \multirow[t]{3}{*}{ Logout } & 7 & Sangat Penting Dari \\
\hline & 8 & Medekati Mutlak Dari \\
\hline & 9 & Mutlak Sangat Penting Dari \\
\hline
\end{tabular}

Gambar 3. Tampilan Nilai Preferensi

\section{Kesimpulan}

Kesimpulan dari penelitian :

1. Perhitungan metode Analytic Hierarchy Process (AHP) Untuk Menentukan Pemutusan Hubungan Kerja Karyawan CV.BIRING NDU CAHAYA PANGLONG, berdasarkan perhitungan dan perangkingan nama Arya Sinaga adalah nama karyawan yang paling sesuai untuk Pemutusan Hubungan Kerja dengan nilai 0.272435 .

2. Sistem Pendukung Keputusan Untuk Menentukan Pemutusan Hubungan Kerja Karyawan ini dirancang dengan menggunakan UML (Unified Modeling Language.) yang dapat menjadi acuan untuk Pemutusan Hubungan Kerja Karyawan CV. Biring Ndu Cahaya Panglong.

\section{Daftar Pustaka}

[1] R. P. Darmawan, "Analisa Pemilihan Karyawan Terbaik Untuk Promosi Jabatan Supervisor Dengan Metode Analytical Hierarchy Process Di Pt. Karya Indah Alam Sejahtera," Matrik, vol. XVII, no. Vol 17 No 2 (2017), pp. 1-6, 2017.

[2] S. B. Wibowo and M. Marbun, "Penentuan Mahasiswa Berprestasi dengan Metode Ahp di STMIK Pelita Nusantara," J. Nas. Komputasi dan Teknol. Inf., vol. 1, no. 2, p. 268073.

[3] R. S. Ilhami and D. Rimantho, "Penilaian Kinerja Karyawan dengan Metode AHP dan Rating Scale," $J$. Optimasi Sist. Ind., vol. 16, no. 2, p. 150, 2017.

[4] D. Lestari and A. S. R. Sinaga, "Penentuan Karyawan Kontrak Menjadi Karyawan Tetap PT. Timbang Deli Dengan Metode Analitycal Hierarchy Process (AHP),” J. Teknol., vol. 8, no. 2, pp. 27-37, 2018.

[5] K. Makkasau, "Use of Analytic Hierarchy Process (Ahp) Methods in Determining the Priority of Health Programs (Case Study of Health Promotion Program),” J@TI Undip, vol. VII, no. 2, pp. 105-112, 2012.

[6] Masitha, D. Hartama, and A. Wanto, "Analisa Metode (AHP) Pada Pembelian Sepatu Sekolah Berdasarkan Konsumen,” Semin. Nas. Sains dan Teknol. Inf., pp. 338-342, 2018.

[7] B. H. Muhaimin Hasanudin, Yansen Marli, "Sistem Pendukung Keputusan Pemilihan Karyawan Terbaik Menggunakan Metode Analytical Hierarchy Process ( Studi Kasus Pada Pt . Bando Indonesia )," Semin. Nas. Teknol. Inf. dan Multimed. 2018, vol. 6, no. 3, pp. 91-96, 2018.

[8] S. Saefudin and F. Cahyo, "Sistem Pendukung Keputusan Menentukan Pemberian Bonus Tahunan Pada Karyawan Menggunakan Metode Analytical Hierarchy Process (Ahp)," JSiI (Jurnal Sist. Informasi), vol. 6, no. 1, p. 54, 2019.

[9] D. R. Sari, A. P. Windarto, D. Hartama, and S. Solikhun, "Decision Support System for Thesis Graduation Recommendation Using AHP-TOPSIS Method," J. Teknol. dan Sist. Komput., vol. 6, no. 1, pp. 1-6, 2018.

[10] A. S. R. Sinaga and J. Purba, "Penentuan Karyawan Lembur Dengan Metode Analytical Hierarchy Process ( Ahp )," vol. 1, no. 2, pp. 40-50, 2018.

[11] R. W. dan A. Sindar, "Sistem Pakar Menentukan Jenis Gangguan Perkembangan Anak Menggunakan 
Metode Certainty Factor," vol. 1, no. 2, pp. 1-4, 2020.

[12] R. Umar, A. Fadlil, and Y. Yuminah, "Sistem Pendukung Keputusan dengan Metode AHP untuk Penilaian Kompetensi Soft Skill Karyawan," Khazanah Inform. J. Ilmu Komput. dan Inform., vol. 4, no. 1, p. 27, 2018.

[13] E. Wiyanti and A. Sindar, "Implementasi Analytical Hierarchy Process dalam Menentukan Tingkat Kepuasan Pelayanan E-ktp (Studi Kasus Kantor Camat Pagar Merbau)," J. Nas. Komputasi dan Teknol. Inf., vol. 1, no. 2, 2018. 